\title{
Vegetation types classification of a temperate biosphere reserve in China by multisensor satellite imagery
}

\author{
マルチセンサーデータによる中国温帯地域における \\ 生物保護区の植生タイプの分類
}

\author{
Qi-Jing LIU* $\cdot$ Ryutaro TATEISHI* - Akihiko KONDOH* \\ and Nobuo TAKEUCHI* \\ 劉琪璟 - 建石隆太郎 - 近藤 昭彦 - 竹内 延夫
}

\begin{abstract}
Vegetation cover types on Changbai mountain, a natural biosphere reserve $\left(2000 \mathrm{~km}^{2}\right)$ in northeast China, were derived by using multisensor satellite imagery combined with Landsat TM and JERS1 OPS. DEM data were used for improving classification accuracy. Cover types were classified into 20 groups. Bands 4 and 5 of Landsat TM image acquired on July 18, 1997 and band 1 of JERS1 OPS image acquired on Feb. 4, 1997 were fused to a false color image for the final output, and maximum likelihood supervised classification was performed. Data fused either with multitemporal (OPS) or with multisensor (TM+OPS) showed a high accuracy of identification, comparing to individual images. The overall accuracy of classification of individual images of OPS presented less than $40 \%$, and TM less than $70 \%$, while the fused data set provided an accuracy higher than $73 \%$ which was raised to $83 \%$ by post classification including filtering and verification with DEM.

There were 5 vegetation zones on the mountain, from the base to the peak, deciduous forest zone, mixed forest zone, conifer forest zone, birch forest zone, and tundra zone. Spruce-fir conifer forest was the most dominant (nearly $50 \%$ ) vegetation type, followed with mixed forest (10\%) and larch forest (8\%). Classification accuracy was not only determined by data fusion from different sensors of different resolutions, but was also affected by image composite from different seasons. In winter images, the contrast between cover types in life-form level, e.g. evergreen and summer-green, or forest and meadow, is enhanced, while more detailed information of spectral characteristics of plant communities can be extracted from summer images. For boreal vegetation, autumn imagery is considered useful for discriminating cover types, because the leaf color in this season is significantly diversified. It is concluded that, for vegetation consisting of conifer and deciduous species, multitemporal imagery fused from phenologically different data is meaningful for creating vegetation maps with high accuracy.
\end{abstract}

Key words: Changbai mountain, Landsat TM image, JERS-1 OPS, supervised classification, image fusion

和文摘要：本研究は Landsat TM と JERS-1 OPS の 画像融合によって，中国の東北にある長白山自然保護 区 (面積 $2000 \mathrm{~km}^{2}$ ) の植生タイプを判読し, 植生図を作 成した。また, DEM データを用いて分類精度を向上さ せた。被覆タイプは20のグループに分類した。Landsat $\mathrm{TM}$ (バンド 4，5）（1997年 7 月18日）と JERS-1 OPS (バンド 1 ) (1997年 2 月 4 日)を合成して，フォールス

*Center for Environmental Remote Sensing, Chiba University

千葉大学環境りモートセンシング研究センター

1-33 Yayoi-cho, Inage-ku, Chiba City 263-8522, Japan

テ263-8522 千葉市稲毛区弥生1-33

「写真測量とリモートセンシング」VOL. 39，NO. 5，2000
カラーイメージを作った上, 教師付き分類を行った。 OPSの多時期画像の融合も試した。いずれの場合, 融 合画像による分類の精度は単一センサ一或いは単時期 データより判読の精度が高いことを示した。OPS 単時 期イメージの判読の全体的精度は $40 \%$ 以下, TM 画像 は70\%以下であるのに対して, 融合した画像による分 類精度は73\%であった。DEM データとフィルターを 使って修正したあとの精度は $83 \%$ となった。長白山の 植生は下から上へ落葉樹林带, 針広交混林帯, 針葉樹 林带, ダケカンバ林帯, およびッンドラ帯という5つ の植生带によって構成されている。中では, 針葉樹林 の面積優占度は最も高く、ほぼ50\%を占めており, 針 広交混林は $10 \%$, カラマツ林は $8 \%$ であった。冬の画 
像において，生活形レベルの差異，例えば，常緑樹林 と落葉樹林或いは森林と草地等が強調される。一方, 夏季の画像により，植物群落のスペクトルの特性につ いての詳細な情報が得られる。北方植生にとって, 葉 色がもっとも多様である秋の画像は，カバー夕イプを 識別するのに理想的であると考えられる。結論として， フェノロジ一的差異の大きいデータの融合が高精度の 植生地図を作るために重要である。 キーワード：長白山, Landsat TM, JERS-1 OPS, 教師付き分類，画像融合

\section{Introduction}

Inventory of natural resources by satellite remote sensing is very time- and cost-effective, especially for regional scales and topographically inaccessible areas. For natural reserves, the status and its changes of the bioecosytem with time need detailed information about the community types.

High resolution data, e.g. Landsat TM, JERS-1 OPS, and SPOT HRV, make it possible that the distribution of vegetation types in any year/season can be derived by using satellite data. This study is aimed at making the vegetation map of Changbai mountain in northeast China by using satellite imag. ery, which is an very important boreal ecosystem in China as well as in the world, because of the high diversity in plant species and community types.

Data from different sources and seasons can show different separability. In regarding with the study objects, the accuracy of classification by imagery can be affected by many factors, e.g., stand age (Mickelson et al. 1998, Abuelgaim et al. 1999), understorey structure (Spanner et al. 1990, Curran et al. 1992, Joffre et al. 1993, Nemani et al. 1993), tree height, live basal area, leaf area index (LAI), tree size (Nilson et al. 1995, Jakubauskas 1996), and density or timber volume (Gemmell 1995, Trotter et al. 1997), etc..

Similarly, classification accuracy can be significantly improved by using multi-season imagery (Jeon et al. 1999, Kurosu et al. 1999) and multisensor data (Gong et al. 1994, Dai et al. 1998, Toutin 1998,
Haack et al. 1999, Zhukov et al. 1999, Michelson et al. 2000). Assistant data like DEM (digital elevation model) are also useful.

For the target area of this study, Shao et al. (1996) classified the vegetation into 14 cover types by using bands 2,4 , and 5 of a single TM image with ISODATA method. The results indicated that band combination is most sensitive to forest types. However, the evergreen conifer forest was grouped into one category, which has at least two types, pine dominated and spruce dominated stands. Therefore, additional data like DEM and phenological information from different seasons, instead of using one -date data, are expected to improve the classification.

This study is the first attempt to use multisensor imagery, with DEM data, for cover types detection for the Changbai Mountain Natural Reserve, which is a very important ecosystem representing the temperate vegetation of the northern hemisphere, because it is rich in biodiversity and community types. The vertical distribution of vegetation zones is very consistent with the horizontal alternation from temperate region to the arctic. The purpose of this study is to map the vegetation types of the mountain by using remote sensing data.

\section{Study area and methods}

\subsection{Study area}

Study area was the Changbai Mountain Natural Reserve which is located on the border between China and North Korea, and the coordinates are $127^{\circ} 42^{\prime} E / 41^{\circ} 41^{\prime} N-128^{\circ} 17^{\prime} E / 42^{\circ} 26^{\prime} N$ (Figure 1). The area of the reserve is about $2000 \mathrm{~km}^{2}$. The ranges of the reserve are $60 \mathrm{~km}$ south-north and $40 \mathrm{~km}$ east -west. The highest elevation is $2734 \mathrm{~m}$ above sea level (asl).

The vegetation is vertically divided into 5 zones, and there are 3 forest zones inside the reserve, i.e. (1) broad-leaved-conifer mixed forest zone (600$1100 \mathrm{~m}$ asl), dominated by Korean pine (Pinus koraiensis), bass (Tilia amurensis), maple (Acer mono), 


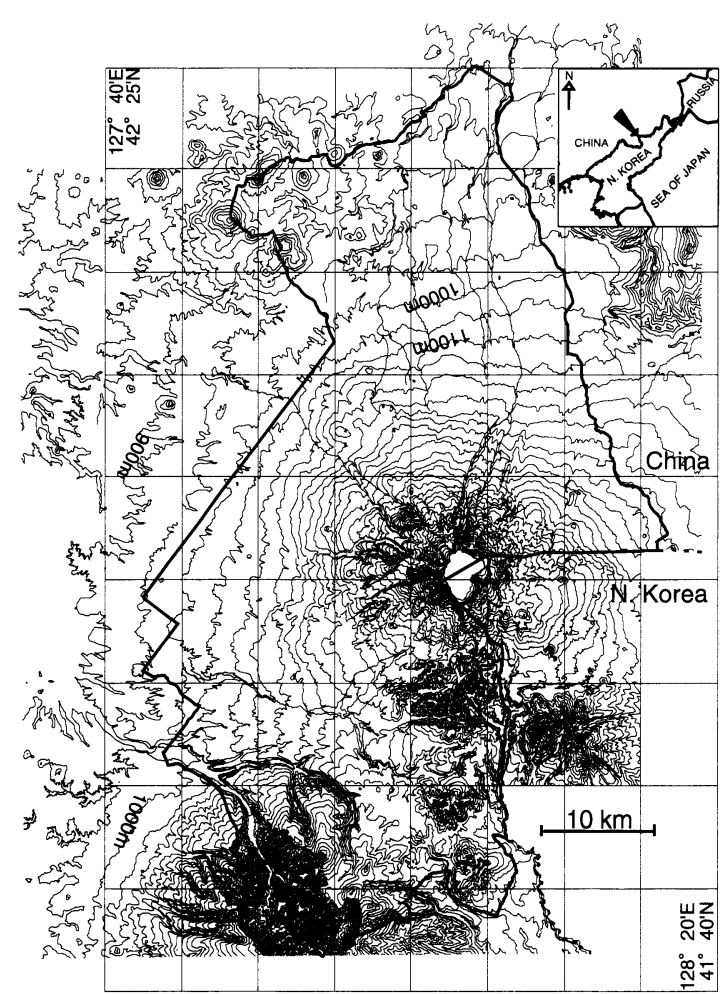

Figure 1. Contour map of the Mt. Changbai Natural Reserve.

elm (Ulmus propinqua) etc., (2) conifer forest zone (1 100-1700m asl), dominated by spruce (Picea jezoensis var. komarovii, P. koraiensis) and fir (Abies nephrolepis), and (3) mountain birch forest zone (1700-2000m asl), dominated by mountain birch (Betula ermanii), except for the east slope which is occupied by larch (Larix olgensis). The evergreen component increases towards the upper limit $(1700 \mathrm{~m}$ asl) of the conifer forest zone, and disappears in the mountain birch forest zone (Liu et al. 1998).

In lower elevations, secondary vegetation of poplar birch forest, dominated by poplar (Populus davidiana) and white birch (Betula platyphylla), and oak (Quercus mongolica) is very common.

The deciduous forest is mainly mixed hardwood forest and birch-poplar forest. Oak forest is also frequently encountered in the lower areas, which is a secondary vegetation after repeated cutting.

\subsection{Data}

Landsat TM image acquired on Jul. 18, 1997, JERS-1 OPS data acquired on Feb. 4, 1997 (OPS97) and Mar. 7, 1998 (OPS98) were used for cover types identification, which were provided by NASDA (National Space Development Agency of Japan).

Spectral radiance, represented by digital value, was selected for typical vegetation types which were represented by 20 sample points, and the radiance of each sample point was expressed by the average value of 9 pixels ( 3 by 3 pixels).

A 1: 100000 scale contour map, published by the former Soviet Union in 1982, was scanned with a drum scanner for geometric correction.

The contour map was also digitized with a software called ATLAS GIS ( $\mathrm{Q}+\mathrm{E}$ Software, Inc.). The digital map was then converted into ASCII format, and a grid file was created by Minimum Curvature method with SURFER (Golden Software Inc.), and the grid size was set consistent with satellite imagery. The generated data set (DEM file) was imposed onto the classified image for verifying cover types. This is expected to be meaningful for distinguishing the different types of vegetation, especially conifer forest, which are similar in spectral reflectance.

Geometric correction was performed with fourth order polynomial, and the error was controlled less than one pixel. For each image (TM 1995 pixels $\times$ 2842 lines and OPS 3325 pixels $\times 4737$ lines), more than 100 ground control points (GCP) were picked. Radiometric correction was not performed.

Image processors for the analysis were PCI (PCI Ltd.) and ER Mapper (Earth Resource Mapping Pty Ltd.)

Data fusion was performed on the 2 sensors. OPS imagery has a spatial resolution of $18 \mathrm{~m} \times 24 \mathrm{~m}$, which was resampled to $18 \mathrm{~m} \times 18 \mathrm{~m}$ by data provider (NASDA). TM imagery was resampled from the original $30 \mathrm{~m} \times 30 \mathrm{~m}$ to $18 \mathrm{~m} \times 18 \mathrm{~m}$ by nearest distance method in order to be overlaid with OPS image.

\subsection{Ground data}

Ground data were obtained by field investigation. 
More than 100 plots were surveyed, including some permanent ones. The detailed information about plant communities were recorded for three layers, $i$. $e$. tree layer, shrub layer, and herb layer. Tree diameter at breast height $(\mathrm{DBH})$ was recorded with plot sizes ranging from $10 \mathrm{~m} \times 50 \mathrm{~m}$ to $100 \mathrm{~m} \times 100 \mathrm{~m}$. For shrub and herb layers, height, density and coverage were measured with quadrat sizes of $2 \mathrm{~m} \times 2 \mathrm{~m}$ and $1 \mathrm{~m} \times 1 \mathrm{~m}$, respectively.

\subsection{Classification procedure}

Maximum likelihood supervised classification was applied for image analysis, before which ISODATA unsupervised classification was performed with various combinations of channels from different dates. By comparing the classification results, suitable combination of bands/sensors was selected.

Based on the vegetation composition in and around the reserve, it was grouped into 20 cover types by supervised classification. Typical vegetation for each category was selected as training area (more than 250 pixels for each class) for the classification, which was also used as testing area for accuracy assessment. The accuracy was estimated with the equation of $P_{i}=n_{i} / N_{i}$, where $P_{i}, n_{i}$ and $N_{i}$ are accuracy (\%), the number of pixels which are correctly classified, and the total number of pixels of cover type $i$ in the testing area, respectively. Overall accuracy was calculated with $n / N$, where $n$ and $N$ are the total number of pixels of all cover types correctly classified and the total number of pixels of the entire testing area, respectively. Average accuracy was based on $\sum P_{i} / S$, where $S$ is the number of cover types (classes), in this study $S$ was 20.

With the knowledge on the relationship between vegetation and elevation, the derived image was verified with DEM data. Then the classified image was smoothed with the Median filter of $9 \times 9$ window to remove noise or tiny points.

\section{Results}

In this section, spectral radiance of different vegetation types in the two sensors are presented.

\subsection{TM imagery}

As Figure 2 shows, for the case of TM image, vegetation types were clearly differentiated in bands 4 and 5 . Bands 1 and 7 showed little difference between cover types.

As a whole, the spectral radiance showed low in bands 1, 2, 3 and 7, and high in bands 4 and 5. In particular, band 4 showed meaningful for cover types interpreting. This pattern reveals the spectral -vegetation relationship that, for visible areas, the absorption by pigments of tree leaves is active, and the radiance was therefore very low. Contrary to this, the NIR band (B4) was vigorous in penetration and reflection (Japan Society of Remote Sensing 1997), and presented high in radiance.

The meadow, consisting of high grass, performed a high level of radiance, and water presented the

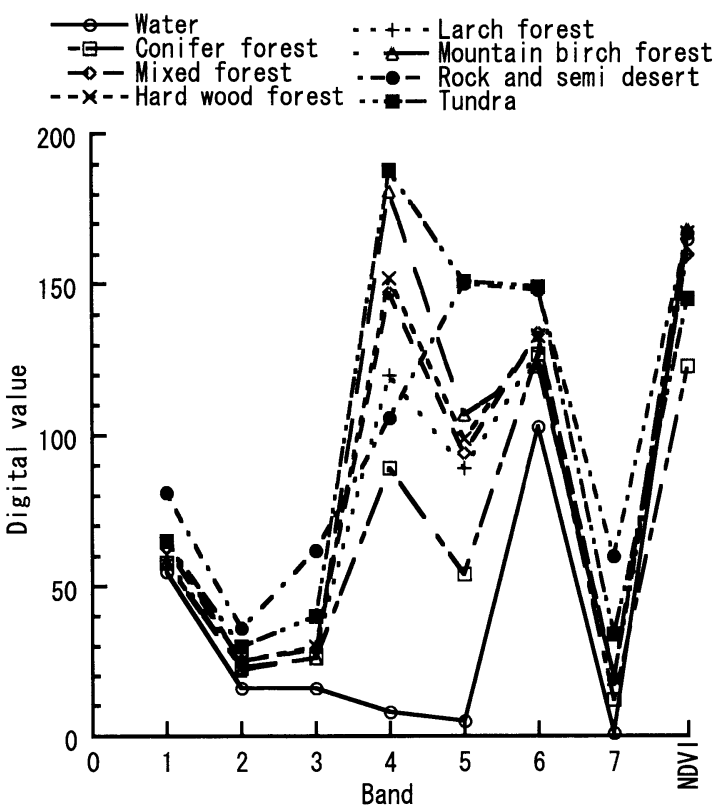

Figure 2. Landsat TM spectral radiance of the main vegetation types in Mt. Changbai. Image was acquired on July 18, 1997. Radiance is represented by digital values. 
opposite. Tundra was similar to meadow in physiognomy, and the radiance was slightly lower than the meadow was. This phenomenon implies the difference in utilization of solar radiation, i.e. strong in dense-and-high forest and weak in thin-and-young stands.

Radiance in the forest vegetation was strongly effected by species composition. The pure Changbai pine forest, outside the reserve, showed the lowest among all forest types, and the mountain birch forest presented the highest. The canopy color of spruce-fir forest is very similar to the pine forest, but the spectral radiance presented near the same as mixed forest and deciduous forest. In fact, the spruce-fir forest on higher elevations was mixed with larch and birch (Liu et al. 1998), and these deciduous species with bright color may have made the radiance of the forest higher than pure conifer forest stand.

The difference of vegetation types in spectral radiance is considered to be largely led by the stand structure and green leaf biomass or stand volume, according to previous reports (Rey-Benayas et al. 1995, Kilpelainen et al. 1999). Also, the brightness of broad leaves are different from needle leaves, the former is brighter than the latter.

The leaf biomass was significantly different among cover types, 3.31 tons/ha in mountain birch forest, 7.02 tons/ha in mixed forest, 5.68 tons/ha in larch forest, and 18.96 tons/ha in the subalpine conifer forest ( $\mathrm{Li}$ et al. 1981). In reverse, this may reveal the variation in leaf area index, as demonstrated by previous studies on the relationship between spectral radiance and leaf biomass or leaf area index (Chen et al. 1996, Turner et al. 1999). In this study, bands 4, 5 and NDVI showed a high correlation with leaf biomass, that large leaf biomass led to low radiance.

The radiance curve is consistent with the conclusion that spectral reflectance is closely related to stand basal area (Jakubauskas 1996, Moran et al. 1996), and species composition (Cihlar et al. 2000). In this study, the basal area of subalpine conifer forest was $48.75 \mathrm{~m}^{2} /$ ha, the mixed forest was $38.17 \mathrm{~m}^{2} / \mathrm{ha}$, and larch and birch-poplar forest were less than 20 $\mathrm{m}^{2} /$ ha (Liu et al. 1998).

The NDVI showed less important for detecting cover types, because the difference among communities was not significant. However, the vegetation can be roughly divided into 3 categories, conifer forest, tundra and meadow, and others. The vegetation in this season is the most vigorous in photosynthesis, and the deciduous-dominated stands showed higher values than the conifer forest.

It is worth to indicate that the vegetation on the higher areas of alpine, tundra, meadow and semidesert performed high values in near infrared band, and consequently led to the high NDVI. This is considered to be determined by the species characteristics adapted in the bitter environment, that the growing season in the alpine is very short, and the plant species need to finish life cycle in the period, and during which, the activity of chlorophyll is more vigorous than other types of vegetation.

\subsection{OPS imagery}

Both OPS images were received in winter, and the vegetation types similar in life form (evergreen or deciduous) were difficult to distinguish. For instance, tundra and meadow showed little difference in band value. Similar were hardwood forest, mountain birch forest and poplar-birch forest (Figure 3).

The water area was covered by snow, and showed a high radiance, nearly the same as tundra.

The conifer forest was dominated by evergreen species, which showed a dark green color (B321= $\mathrm{RGB}$ ) in the images, and presented the lowest value.

In brief, the difference between cover types in life -form level was enhanced in this season. It is clear that non forest area showed higher radiance than forest, and, for forest vegetation, the high dominance of evergreen species resulted in low radiance, i.e. the mixed forest stood in the intermediate, higher than pure conifer forest but lower than deciduous forest. 


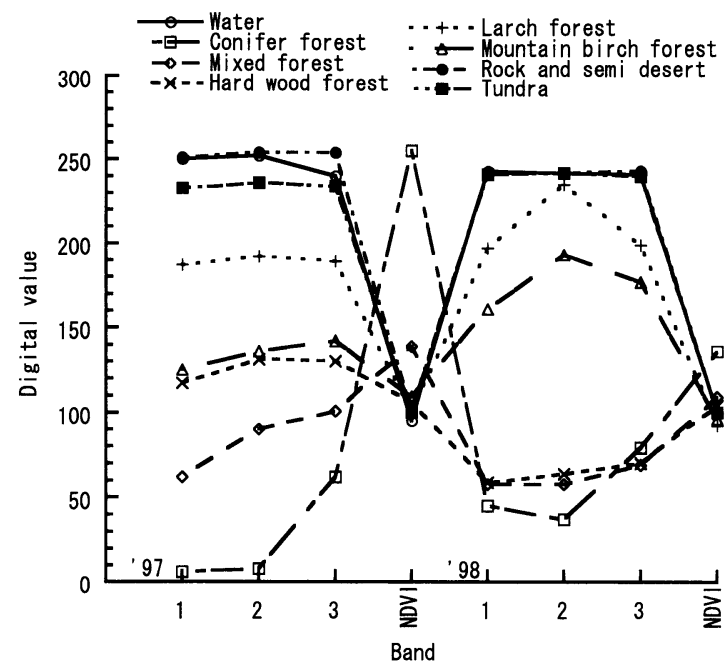

Figure 3. JERS-1 OPS spectral radiance of the main vegetation types in Mt. Changbai. Images were acquired on Feb. 4, 1997 and Mar. 7, 1998. Radiance is represented by digital values.

NDVI presented a reverse trend that the conifer forest was the highest, while other types of pure deciduous communities showed semblable to each other. The mixed forest presented slightly higher values than the summer green areas. This was apparently due to the content of chlorophyll in leaves, that the evergreen conifer species remain unchanged in greenness, while other classes were free of chlorophyll.

As to the separability of OPS sensor, bands 1 and 2 presented similar to each other, and were better than band 3. NDVI is meaningful for distinguishing pure conifer forest from other cover types, which was similar to that of TM image.

The OPS98 image was affected by noise which was larger than the OPS97 image, and the separability was not as good as the 1997 image. Therefore, the OPS98 image was not used for the final output of classification.

With these images taken in winter, finer classification is difficult. Multitemporal images including summer data are expected useful. But for the target area, no more ideal images could be obtained.

\subsection{TM-OPS combination}

TM and OPS97 images were used to make false color images. As mentioned earlier, bands 4 and 5 of TM image presented visible difference between objects, and the difference among the spectral bands of OPS image was not so large.

Classification with various band combinations were attenmted, and it was found that the number of bands used for classification larger thatn 3 showed no better output, by visual verification with a sketch map. The cause for this is considered the inter correlation that bands with similar features may have weekened the contrast of cover types in other bands. Therefore, here we focus on the combinations of TM (B2 and B4) plus OPS97 (B1), and TM (B4 and B5) plus OPS97 (B1). Both false color images showed a clear contrast between cover types, and the output images of classification appeared very similar to each other, and presented a good quality for cover types identification.

Classifications on individual images showed that the vegetation types with less difference in spectral radiance are very difficult to identify, even for those taken in ideal season. For example, the conifer forest, conifer-mixed forest, and even hardwood forest were frequently grouped into one category.

In reverse, the subalpine spruce forest, mountain birch forest, and the forest mixed with other species were very different not only in composition, but also in physiognomy and spatial structure. Precise identification with individual images, however, was very difficult. Because different vegetation may behave the same in spectral relectance in one season, and differ significantly in another season. Also, since sensitivities of spectra are different among objects, the fused multisensor image was helpful for improving the accuracy of classification.

\subsection{Supervised classification}

Classification was performed on 8 combinations of the 3 data sets (Table 1). The results showed that the accuracy by multi-temporal imagery was higher than by single-date data, and higher by fused data 
Table 1. Classification accuracy (\%) by different fusion of images of Landsat TM and JERS-1 OPS. TM : TM (B245), OPS : OPS97 (B123) + OPS98 (B123), 097 : OPS97 (B123), O98: OPS98 (B123), TO1: TM (B24) + OPS97 (B1), TO2: TM (B24) + OPS98 (B1), T03: TM (B45) + OPS97 (B1), T04: TM (B45) + OPS98 (B1)

\begin{tabular}{lrrrrrrrrr}
\hline Type & Code & TM & OPS & O97 & O98 & TO1 & TO2 & TO3 & TO4 \\
\hline Water & 1 & 100.0 & 12.3 & 4.7 & 61.3 & 100.0 & 100.0 & 100.0 & 100.0 \\
Conifer forest & 2 & 76.5 & 80.6 & 76.4 & 70.8 & 82.1 & 77.5 & 82.2 & 76.6 \\
Mixed forest & 3 & 22.2 & 59.3 & 38.4 & 47.6 & 53.4 & 55.7 & 60.6 & 54.1 \\
Spruce larch forest & 4 & 75.2 & 41.4 & 11.1 & 23.4 & 60.2 & 77.5 & 65.6 & 78.3 \\
Spruce birch forest & 5 & 84.8 & 84.9 & 79.0 & 83.6 & 90.4 & 87.0 & 86.7 & 86.2 \\
Cut area & 6 & 96.4 & 42.9 & 27.6 & 13.3 & 93.0 & 88.7 & 91.1 & 85.3 \\
Hard wood forest & 7 & 79.2 & 97.9 & 65.8 & 96.3 & 83.4 & 93.4 & 76.8 & 94.2 \\
Korean pine forest & 8 & 34.4 & 74.9 & 3.3 & 66.4 & 53.2 & 81.4 & 44.6 & 78.4 \\
Larch forest & 9 & 51.0 & 86.7 & 22.1 & 79.5 & 88.5 & 94.1 & 88.3 & 94.4 \\
Thin conifer forest & 10 & 83.5 & 89.7 & 83.0 & 50.9 & 88.7 & 93.3 & 88.7 & 94.5 \\
Windfall and shrubs & 11 & 89.4 & 79.0 & 85.9 & 23.9 & 93.2 & 59.2 & 91.8 & 79.9 \\
Mountain birch forest & 12 & 84.9 & 65.9 & 46.3 & 43.3 & 85.6 & 86.3 & 79.5 & 83.7 \\
Rock and semi desert & 13 & 61.7 & 45.4 & 45.2 & 4.3 & 80.0 & 90.9 & 75.6 & 87.8 \\
Meadow & 14 & 96.1 & 52.2 & 39.3 & 19.3 & 94.9 & 95.6 & 96.2 & 97.1 \\
Tundra & 15 & 66.6 & 2.9 & 1.8 & 0.3 & 57.0 & 52.7 & 55.6 & 36.1 \\
Urban area & 16 & 85.5 & 98.4 & 56.1 & 96.9 & 96.5 & 99.9 & 95.6 & 99.3 \\
Poplar birch forest & 17 & 68.6 & 83.1 & 38.2 & 72.2 & 67.7 & 79.9 & 71.0 & 79.1 \\
Young forest & 18 & 76.9 & 76.2 & 54.7 & 1.9 & 84.1 & 85.3 & 47.3 & 80.8 \\
Changbai pine forest & 19 & 94.8 & 92.3 & 3.2 & 93.3 & 94.2 & 95.4 & 90.0 & 92.9 \\
Thin forest & 20 & 54.9 & 57.5 & 19.5 & 39.5 & 53.7 & 66.1 & 26.7 & 58.7 \\
Average & & 74.1 & 66.2 & 40.1 & 49.4 & 80.0 & 83.0 & 75.7 & 81.9 \\
Overall & & 69.6 & 53.3 & 37.5 & 35.4 & 75.6 & 73.1 & 74.1 & 71.2 \\
\hline
\end{tabular}

than by imagery of single sensor data.

For OPS imagery, the overall accuracy was less than $40 \%$ by individual images, which was improved to $53.3 \%$ by fusing the 2 temporal images into one data set. The accuracy was not so high in any case, which was mainly due to the leafless season.

As to the TM imagery which was acquired in midsummer, the overall accuracy was nearly $70 \%$, higher than that of the OPS imagery. On the other hand, the accuracy by fused data from different sensors was higher than $70 \%$, and, in most cases, the average accuracy was over $80 \%$.

By comparing the classified images derived from different combinations of bands/sensors, the one derived from the combination of TM (bands 4 and 5 ) and OPS97 (band 1) was selected as the final output, although the accuracy was not the highest, because the output of this combination showed a better consistence with the actual vegetation.

The classified image is shown as Figure 4. The forest under $1100 \mathrm{~m}$ asl was dominated by mixed forest and deciduous forest. The dominance of Korean pine forest showed a big variability, revealing the diverse stages of the community.

The spruce-fir forest on the subalpine differed among slopes. The eastern slope was covered by larch forest, with some spruce patches scattered in. The northern slope was dominated by a relatively pure stand of spruce-fir forest, and between the two types was an intermediate type which was mixed with larch. The western and southern slopes were primarily dominated by spruce-fir-birch forest. The southern slope showed a little complex, a mosaic texture of pure conifer forest, birch-mixed conifer forest, and meadow.

The west-south slope was characterized by the high presence of birch which is very strong to wind blowing. The frequency of strong wind is high in the area, and the formation of birch forest is considered the result of wind disturbance. The subalpine birch 


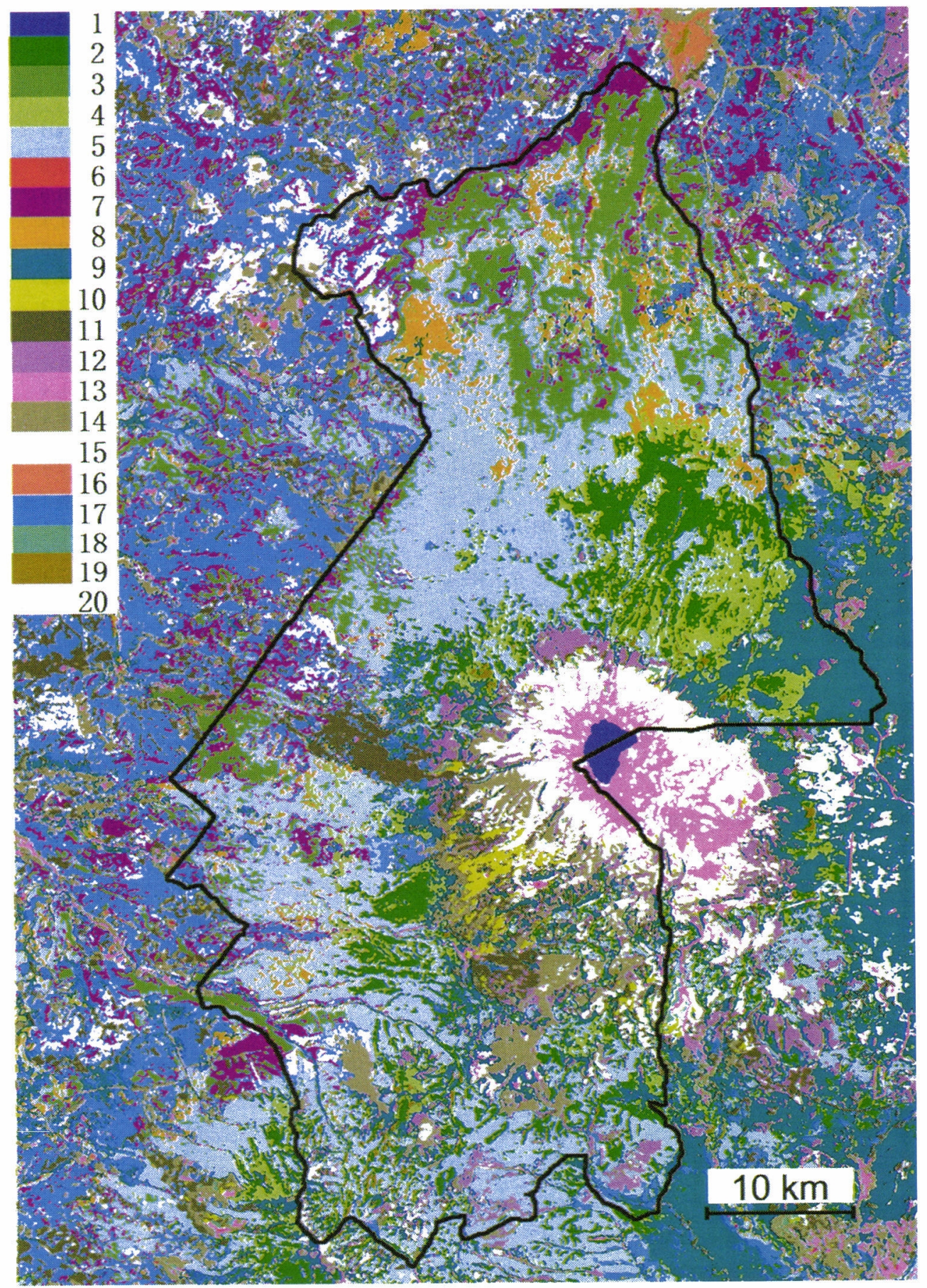

Figure 4. Vegetation map of Mt. Changbai derived by supervised classification of multisensor imagery fused with Landsat TM and JERS-1 OPS. TM image was acquired on July 18 , 1997 (B4 and B5) and OPS on Feb. 4, 1997 (B1). Numbers represent cover types, refer to Table 1 . Image covers $60 \times 85 \mathrm{~km}^{2}$. 
zone is generally determined in the area of $1700-$ $2000 \mathrm{~m}$ asl, but the eastern slope was almost lack of birch. On the western slope, there was little continuum of birch forest, where it can only be found in valleys, especially in the higher elevations.

The so called birch zone was not a circle on the subalpine. The timberline differed among slopes. This is related to volcanic eruptions. The timberline pre-eruption was found to be at about $2200 \mathrm{~m}$ (Liu et al. 1993). The slow recovery of forest in the west side is considered the result of wind oppression.

Forest outside the reserve was mainly deciduous forest or hardwood forest, and little old growth remained.

The proportions of cover types are presented in Table 2. The forest inside the reserve was dominated by spruce forest which had a proportion of $47 \%$. Following which were mixed forest $(10 \%)$ and larch forest $(8 \%)$. Other vegetation types were each less than $5 \%$.

\subsection{Accuracy}

The initial classification presented an average accuracy of $75.7 \%$. By filtering with the Median filter and further by modifying with DEM, the accuracy was raised to $83.1 \%$ (Table 2).

Vegetation with homogeneous structure and uniform composition showed a higher accuracy than those with complex in both species composition and structure. For example, in the meadow and logged areas, it was more than $90 \%$, and that of most forest types was low. Among the forest types, the uniform structure of larch forest presented high versus the species-rich type of mixed forest.

\section{Discussion}

Classification with multitsensor imagery showed a satisfactory result. Because different vegetation types may appear similar in spectral reflection in one season, and very distinguishable in other periods. Such temporal variability of cover types

Table 2. Coverage of vegetation types of post classification. Inside-Coverage

(\%) inside the reserve. Outside-Coverage (\%) outside the reserve.

Acu 1 -Initial accuracy (\%), Acu2-Accuracy (\%) after filtering and

DEM verification. The area of the reserve is $2000 \mathrm{~km}^{2}$.

\begin{tabular}{clrrrr}
\hline Code & Type & Inside & Outside & Acu1 & Acu2 \\
\hline 1 & Water & 0.21 & 0.17 & 100.0 & 100.0 \\
2 & Conifer forest & 10.01 & 2.56 & 82.2 & 93.0 \\
3 & Mixed forest & 10.44 & 5.11 & 60.6 & 68.0 \\
4 & Spruce larch forest & 7.85 & 1.66 & 65.6 & 85.0 \\
5 & Spruce birch forest & 28.85 & 8.62 & 86.7 & 100.0 \\
6 & Cut area & 0.01 & 0.10 & 91.1 & 90.0 \\
7 & Hard wood forest & 4.22 & 8.77 & 76.8 & 98.0 \\
8 & Korean pine forest & 3.94 & 1.65 & 44.6 & 47.0 \\
9 & Larch forest & 8.10 & 13.76 & 88.3 & 96.0 \\
10 & Thin conifer forest & 1.00 & 0.20 & 88.7 & 99.0 \\
11 & Windfall and shrubs & 3.76 & 6.86 & 91.8 & 99.0 \\
12 & Mountain birch forest & 4.31 & 2.38 & 79.5 & 97.0 \\
13 & Rock and semi desert & 1.74 & 3.66 & 75.6 & 89.0 \\
14 & Meadow & 4.43 & 8.46 & 96.2 & 100.0 \\
15 & Tundra & 4.49 & 2.86 & 55.6 & 85.0 \\
16 & Urban area & 0.01 & 0.44 & 95.5 & 96.0 \\
17 & Poplar birch forest & 4.68 & 29.11 & 71.0 & 84.0 \\
18 & Young forest & 0.08 & 0.19 & 47.3 & 33.0 \\
19 & Changbai pine forest & 0.41 & 0.12 & 90.0 & 96.0 \\
20 & Thin forest & 3.31 & 1.47 & 26.7 & 6.0 \\
\hline & Total or average & 100 & 100 & 75.7 & 83.1 \\
\hline
\end{tabular}


requires band combination of images from different seasons.

The spectral radiance of forest vegetation in relation with composition can be summarized as follows. The spectral radiance was high in deciduous forest, and low in conifer forest. NDVI was the reverse, high in conifer forest, and low in the deciduous forest. The mixed forest presented in the intermediate level. This difference was considerably large in winter. It is concluded that the conifer forest can be easily separated from other types by using either visible bands or band ratios like NDVI, especially in leafless season.

Forest composition is not the only factor affecting reflectance. As indicated earlier, stand structure like basal area or stand volume can contribute significantly to spectral behavior. Stand density is an alternative form of biomass or stand volume. In relatively thin area, undrestory is an important part contributing to canopy reflectance (Chen et al. 1996, Mickelson et al. 1998), and spectral performance may show some perturbation with season. Contrary to this, dense stands show stable in radiance. This was demonstrated in this study.

The study area is complex in topography, ranges from $600 \mathrm{~m}$ to $2700 \mathrm{~m}$ asl. The vegetation differentiates along elevation. However, the spectral characteristics of some types were not so distinguishable, although the conifer forest, for example, from the base to the timber line altered in species composition. By imposing DEM data on the image after initial classification, the differences among coniferous forest types were enhanced, and more detailed information was able to be extracted.

For the study area, the vertical differentiation is very typical, and DEM data are thus ideal for such areas. The vegetation map created by post classification proved relatively consistent with the actual vegetation.

Supervised and unsupervised classification are two basic methods in remote sensing, and are typically used techniques for forest inventory (White et al. 1995). Unsupervised classification may be prefer- able when mapping large areas with a rugged terrain. Supervised classification can be costly in terms of time and money spent selecting and sampling training sites to represent the range of morphological and topographical variation of a particular mapping category (Walsh 1980). Generally, supervised classification is considered more reliable than unsupervised classification, especially for cover types with similar reflectance, while unsupervised classification is acceptable when the contrast in spectral reflectance is large between them (Thomson et al. 1998). In this study, the supervised classification showed a satisfactory result.

Since the differentiation of canopy colors in autumn is the most visible in the year, images taken in this period, instead of winter, are expected meaningful for improving the classification accuracy.

\section{Acknowledgments}

We gratefully thank Prof. Tamio Takamura for providing satellite data. We also thank the Changbai Mountain Forest Ecosystem Research Station, The Chinese Academy of sciences for support for the field investigation.

(受理日2000.3.17, 受付日2000.9.11)

\section{References}

1) Abuelgasim, A.A., Ross, W.D., Gopal, S. and Woodcock, C.E. 1999, Change detection using adaptive fuzzy neural networks environmental damage assessment after the Gulf War, Remote Sensing of Environment, 70 (2), 208-223.

2 ) Chen, M. and Cihlar, J. 1996, Retrieving Leaf Area Index of Boreal Conifer Forests Using Landsat TM Images. Remote Sensing of Environment, 55 (2), 153-162.

3 ) Cihlar, J., Latifovic, R. Chen, J., Beaubien, J. and Li, Z. 2000, Selecting Representative High Resolution Sample Images for Land Cover Studies. Part 1 Methodology. Remote Sensing of Environment, 71 (1), 26-42.

4 ) Curran, P.J., Dungan, J.L. and Gholz, H.L. 1992, 
Seasonal LAI in slash pine estimated with Landsat TM. Remote Sensing of Environment, 39, 313.

5 ) Cracknell, A.P. 1999, Twenty years of publication of the International Journal of Remote Sensing. International Journal of Remote Sensing, 20 (18), 3469-3484.

6 ) Dai, X. and Khorram, S. 1998, Hierarchical methodology framework for multisource data fusion in vegetation classification. International Journal of Remote Sensing, 19 (18), 3697-3701.

7 ) Gemmell, F.M. 1995, Effects of forest cover, terrain, and scale on timber volume estimation with thematic mapper data in a rocky mountain site. Remote Sensing of Environment, 51 (2), 291305.

8 ) Gong, P., Miller, J. and Spanner, M. 1994, Forest canopy closure from classification and spectral unmixing of scene components - multisensor evaluation of an open canopy, IEEE Transactions on Geoscience and Remote Sensing, 32 (5), 1067-1073.

9) Haack, B. and Bechdol, M. 1999, Multisensor remote sensing data for land use/cover mapping, Computers, Environment and Urban Systems, 23 (1), 53-69.

10) Jakubauskas, M.E. 1996, Canonical correlation analysis of coniferous forest spectral and biotic relations. International Journal of Remote Sensing, 17 (12), 2323-2332.

11) Japan Society of Remote Sensing 1997, Handbook of Remote Sensing (Tokyo: National Space Development Agency), 281 pp. (in Japanese).

12) Jeon, B. and Landgrebe, D.A. 1999, Decision fusion approach for multitemporal classification, IEEE Transactions on Geoscience and Remote Sensing, 37 (3), 1227-1233.

13) Joffre, R. and Lacaze, B. 1993, Estimating tree density in oak savanna-like 'dehesa' of southern Spain from SPOT data. International Journal of Remote Sensing, 14, 685-697.

14) Kilpelainen, P. and Tokola, T. 1999, Gain to be achieved from stand delineation in LANDSAT TM image-based estimates of stand volume.
Forest Ecology and Management, 124, 105-111.

15) Kurosu, T., Uratsuka, S., Maeno, H. and Kozu, T. 1999, Texture statistics for classification of land use with multitemporal JERS-1 SAR single -look imagery. IEEE Transactions on Geoscience and Remote Sensing, 37 (1), 227-235.

16) Li, W.H., Deng, K.M. and Li F. 1982, Study on biomass and primary production of main ecosystems in Changbai mountain. Research of Forest Ecosystem, 2, 34-55 (in Chinese).

17) Liu, Q.J., Kondoh, A. and Takeuchi, N. 1998, The forest vegetation and its differentiation under disturbance in a temperate mountain, China. Japanese Journal of Forest Research 3 (2), 111-117.

18) Liu, Q.J., Wang, Zh. and Wang, Sh. 1993, The effects of volcanic eruption on subalpine vegetation of Changbai mountain. Geologica Scienta Sinica, 13 (1), 51-67 (in Chinese).

19) Mickelson, J.G.Jr., Civco, D.L. and Silander, J. A.Jr. 1998, Delineating forest canopy species in the northeastern United States using multi-temporal TM imagery. Photogrammetric Engineering and Remote Sensing, 64 (9), 891-904.

20) Michelson, D.B., Liljeberg, B.M. and Pilesjo, P. 2000, Comparison of Algorithms for Classifying Swedish Landcover Using Landsat TM and ERS -1 SAR Data. Remote Sensing of Environment, 71 (1), 1-15.

21) Moran, E.F., Packer, A., Brondizio, E. and Tucker, J. 1996, Restoration of vegetation cover in the eastern Amazon. Ecological Economics, 18 (1), 41-54.

22) Nemani, R., Pierce, L. and Running, S. 1993, Forest ecosystem processes at the watershed scale: Sensitivity to remotely-sensed Leaf Area Index estimates. International Journal of Remote Sensing, 14, 2519-2534.

23) Nilson, T. and Olsson, H. 1995, Effect of thinning cutting on boreal forest reflectance : a comparison of simulations and Landsat TM estimates, International Journal of Remote Sensing, 16 (15), 29-63. 
24) Rey-Benayas, J.M. and Pope, K.O. 1995, Landscape ecology and diversity patterns in the seasonal tropics from Landsat TM imagery. Ecological Applications, 5 (2), 386-394.

25) Shao, G., Zhao, G., Zhao, SH., Shugart, H. H., Wang, SH. and Schaller, J. 1996, Forest cover types derived from Landsat Thematic Mapper imagery for Changbai mountain area of China. Canadian Journal of Forest Research, 26 (2), 206216.

26) Spanner, M.A., Peirce, L.L., Peterson, D.L. and Running, S.W. 1990, Remote sensing of temperate coniferous forest leaf area index. The influence of canopy closure, understorey vegetation and background reflectance. International Journal of Remote Sensing, 11, 95-111.

27) Thomson, A.G., Fuller, R.M. and Eastwood, J. A. 1998, Supervised versus unsupervised methods for classification of coasts and river corridors from airborne remote sensing. International Journal of Remote Sensing, 19 (17), 3423-3431.

28) Toutin, T. 1998, SPOT and Landsat stereo fusion for data extraction over mountainous areas. Photogrammetric Engineering and Remote
Sensing, 64, 109-113.

29) Trotter, C.M., Dymond, J.R. and Goulding, C.J. 1997, Estimation of timber volume in a coniferous plantation forest using Landsat TM. International Journal of Remote Sensing, 18 (10), 2209-2223.

30) Turner, D.P., Cohen, W.B., Kennedy, R.E., Fassnacht, K.S. and Briggs, J.M. 1999, Relationships between leaf area index and Landsat TM spectral vegetation indices across three temperate zone sites. Remote Sensing of Environment, 70 (1), 5268

31) Walsh, S.J. 1980, Coniferes tree spedies mapping using Landsat data. Remote Sensing of Environment, 9, 11-26.

32) White, J.D., Kroh, G.C. and Pinder, J.E. I. 1995, Forest mapping at Lassen volcanic national park, California, using Landsat TM data and a geographical information system. Photogrammetric Engineering and Remote Sensing, 61 (3), 299--305. 33) Zhukov, B., Oertel, D., Lanzl, F., and Reinhaeckel, G. 1999, Unmixing-based multisensor multiresolution image fusion. IEEE Transactions on Geoscience and Remote Sensing, 37 (3 I), 12121226 . 